\title{
Advantages and Disadvantages of Reconstruction ${ }^{1}$
}

\section{BUDAHÁZI Árpád ${ }^{2}$}

\begin{abstract}
Since the 19th century, reconstruction was introduced to and was known to Hungarian criminal procedures. Since the very beginning, it has been used to replicate the event, phenomenon, action or any of their parts under the same circumstances as they could have actually happened. The results of reconstruction are expected to verify or confute the testimony of the witness or the defendant. Furthermore, it is also a measure of credibility investigations, whereas the proceeding authority is checking whether the actions could take place as suspected upon the available data. However, it is questionable, whether reconstruction holds any disadvantages besides its benefits; moreover, we must examine in this paper the reasons behind the rare practice of this evidentiary procedure. It must be further viewed in the paper if there is a correlation between its infrequent application and its legal background.
\end{abstract}

Keywords: reconstruction, credibility examination, testimony, suspect, witness

\section{Regulatory Provisions of Reconstruction}

For decades, reconstruction took place during the crime scene investigation, and it was only awarded with regulatory separateness in the statutory rule No. 8 of 1962 (I. criminal procedural rule, hereinafter: Be. I) While Be. I has called it proof of investigation, Be. II (Act I of 1973 on criminal proceedings) has referred to it as evidentiary proof, and this classification was kept by both Be. III (Act XIX of 1998on criminal proceedings) and Be. IV(Act XC of 2017 on criminal proceedings). The regulatory provisions of reconstruction are placed amongst evidentiary actions: "evidentiary acts are especially the crime scene investigation, the on-site interrogation, the reconstruction, the police line-up confrontation and the instrumental credibility examination."(Section 206 of the Be. IV.) On the one hand, Be. IV alters from the previous Act, namely, it regulates the rules of reconstruction as one of the evidentiary actions, while Be. of 1998 has referred to reconstruction as one of the evidentiary procedures. There is no significant difference between the classifications, nevertheless, a long lasting scientific

The work was created in commission of the National University of Public Service under the priority project PACSDOP2.1.2-CCHOP-15-2016-00001entitled "Public Service Development Establishing Good Governance" in the Egyed István Postdoctoral Program.

2 BUDAHÁZI Árpád, PhD, Police Major, Senior Lecturer, National University of Public Service, Faculty of Law Enforcement, Institute of Criminal Sciences, Department of Criminal Procedure Law.

https://orcid.org/0000-0003-0092-3860, budahazi.arpad@uni-nke.hu 
debate has ended with the conclusion that the title 'evidentiary procedures' was changed to 'evidentiary actions'. Another regulatory change is that besides the court and the prosecutor's office, Be. IV also entitles the investigating authority to order and conduct reconstruction ("the court, the prosecutor's office or the investigating authority may order and conduct reconstruction" [Section 209 (1) of the Be. IV].) In accordance with Section 123 (3) of the Be.of 1998, the investigating authority could order and perform reconstruction, unless otherwise provided by the prosecutor.

Be. IV divides investigation into two phases, namely to intelligence and to the sequence of investigation. Essentially, intelligence focuses on data collection, data that is sufficient enough to disclose the imputation or to conduct the interview of the suspect. Nevertheless, reconstruction does not quite fit into these ambitions, since it requires intense organisation efforts and its preliminary preparation is a time consuming process. However, the preamble to the Be. IV refers to exceptionally typical cases, whereas gathering evidence might be justified, that is true for reconstructions as well, when the authorities aim to verify or confute the statements of the witness during this evidentiary act, or they check whether the suspicions of the authority are correct, or they try to set up new versions upon the known results of the reconstruction. If there is already a suspect to the case and the procedure turns into the investigative phase (whereas the simple preliminary suspicion is specified to the perpetrator and is proved by evidence), ${ }^{3}$ reconstruction may also be used for credibility examination purposes, for both the suspect's statements and the testimony of the witness, also, the same applies for court procedures, as reconstruction may also be conducted during both the first and second instance court procedures.

Detailed provisions of the investigations were implemented in Nyer. [Gov. Decree (100/2018. (VI. 8.) on the detailed rules of the investigation and the preliminary procedure],that came into force on the 1st of July 2018, and which, contrary to Nyor. implemented to Be. of 1998, does not expressly regulate the detailed rules reconstruction but orders to apply the general rules evidentiary procedure. (Sections 68-71 of the Nyer.) In accordance with the provisions of Section 68 (1) of the Nyer. the minutes taken on the evidentiary action must also contain the following - if it is significant with regards to the nature of the evidentiary measure:

a) direction and method of approach of the location of the evidentiary action;

b) description of the location of the evidentiary action;

c) description of the location of the persons and physical evidences, data of the circumstances, and information on where and under what circumstances they were localised.

Principally, sections b) and c) are relevant from the aspect of reconstruction, since it is elemental to document the scene of evidentiary action pursuant to proper introduction of the evidentiary action before court. Substantial minutes help the comparison of the conditions of the crime to the execution circumstances of the evidentiary action.

3 Vári (2014) 177-190. 
This is not only relevant from the aspects of the court procedure or from the viewpoint of evidentiary measures, but from the considerations of the investigation as well, since the results of the evidentiary proof do give some sort of orientation to the investigating authority, giving directions to the prosecutor's office controlling the investigating authority both in the intelligence and investigative parts of the inspection.

The evidentiary action may by interrupted for a longer period of time if further conduct of the evidentiary action can be secured under the same circumstances. In such cases, the authority must make sure of the unchanged circumstances and all and any eventual changes must be recorded in the minutes. [Section 68 (2) of the Nyer.] For example, rain may interrupt the evidentiary proof since it is an obstacle to conduct the visual survey. Not interrupting the experiment would endanger justification of the evidentiary procedure.

Similarly to Nyor., Nyer. also stipulates guidelines regarding the interrogation of the reconstruction's subject. Prior to the reconstruction and with regards to its nature it must be clarified to the necessary extent - upon the interrogation of the affected person if needed:

a) the questions relevant with regards to the conductible evidentiary action, and those to be investigated through the evidentiary procedures;

b) audio-visual and other observational capabilities and state of the examined person, and otherwise any eventual changes of his sensors that occurred since the time of the observation;

c) if the audio, visual or other observational circumstances were significant at the time of the observation or if they shall be significant at the time when the procedural act is conducted;

d) circumstances of the observation, special recognisance or characteristics of the examined person or object that would help the successful identification. [Section 69 (1) of the Nyer.] Clarification of such circumstance is essential for reconstruction. First, it may be checked, whether the circumstances are similar to the particulars of the past event, phenomenon or action, the evidentiary action may be conducted by the authorities to create similar conditions. Even the Nyer. refers to this requirement, stating that as far as possible, the evidentiary action must be conducted under circumstances matching the time of the observation or the particulars known at the time of the observation - with special attention to similar visual, audio and whether conditions, measures and objects necessary for the successful conduct of the evidentiary action.

During the preparation of the evidentiary action, the equipment, measures of physical evidence necessary for successful conclusion of the procedure must be available at the site. [Section 69 (2) of the Nyer.]

In case of urgent necessity, or in case it would not endanger the successful conclusion of the evidentiary procedure, the person affected may be interviewed as part of the evidentiary measure, just prior to the indication of the evidentiary action. In such case, 
his testimony must be included in the minutes taken on the evidentiary procedure. [Section 69 (3) of the Nyer.] Thus Nyer. does refer to the possibility of the interrogation that prevails the evidentiary action in case of urgent necessity as part of the evidentiary action, or in other words if the proceeding authority does not have the chance to make sure that the interrogation could be time-wise separate from the other evidentiary procedure.

In accordance with the provisions of Section70 (2) of the Nyer., the evidentiary act may be conducted at the same time, in the presence of each other if:

a) it is sufficient with regards to the successful conduct of the evidentiary measure or it does not endanger the successful conclusion of the action;

b) undisturbed conduct of the evidentiary procedure cannot be otherwise guaranteed, and influencing the parties affected can be excluded.

Typically, reconstruction is conducted at once, regardless of the number of participants, whether witnesses or defendants. Nyer. allows outsiders to participate in the reconstruction if it is necessary to conduct the reconstruction, under the approval of the outsider party affected. For example, such outsider can be a stuntman, who is not referred to in the Be. IV, however, he might play a significant role in the course of the reconstruction, since he would either play the role of the defendant or the witness in case they would turn down active participation in the reconstruction or they are simply not present. Nevertheless, the outsider cannot be obliged to stay on site in accordance with the provisions of the Nyer. in case he would reject further participation. Should the outsider leave, his replacement must be taken care of [Sections 71(1)-(2) of the Nyer.] Outsiders are only referred to in the provisions on evidentiary procedures in the Nyer., but without any definition whatsoever. As pointed out earlier, such outsiders may be stand-ins or other assistants, or the person who agrees to participate as an indifferent person at the presentation for identification between living persons.

The provisions of Be. on reconstruction are rather short and compact, while properly detailed regulations are placed in the Nyer. I believe, it is not the nature of the legal background that leads to the rare practice of reconstruction.

\section{Characteristics of Reconstruction}

In addition to legal surroundings, we must analyse the objectives of the proceeding authority when it decides on the enactment of reconstruction.

\section{Reconstruction and credibility examination of testimonies}

Reconstruction plays a significant role in credibility examination of testimonies, since the witness must face criminal law consequences if he lies (offence of perjury); it is not applicable for the defendant, whereas the only indictable action related to false testimony of the defendant is the offence of false accusation committed when the accuser gives 
false accusation of a criminal act. Consequently, the defendant's testimony must be treated reservedly; regardless, it is still one of the most significant evidentiary measures, since the perpetrator holds the most information on the circumstances of the offence committed. Similarly to the witness, the defendant shares his cognisance of facts necessary to determine the factual grounds and to decide over the legal dispute (criminal case) with the authority through his statements. ${ }^{4}$ However, he must be taken good care of, in order to secure that he would preferably tell the truth and his confabulations would be detected. Ultimately, it is the decision of the court that determines if the defendant is credible and his statements are reliable. The fact that the analysis of his statement might be conducted priorly, during the course of the investigation, may assist the discretion of the court.

The possibility to examine the accuracy of the testimony of the witness also has a great significance, since despite of his obligation to tell the truth he might conceal, stretch or overstrain the truth, or he might simply misremember the given event, phenomenon or action. It is a well-established and publicly acknowledged thesis of criminalistics that the analysis of the objective circumstance of the cognitive processes pursued by the witness is a very important aspect in the evaluation of evidences of personal nature. ${ }^{5}$ However, the eye-witness might be wrong, as the victim might as well conceal significant information. That is why the possibilities of pseudo- or frame-up accusations must always be examined, especially in case of fundamental or repetitious contradictions observed by the authority regarding different aspects of the case. ${ }^{6}$ For example, such issue may arise upon the witness' misunderstanding of the scene he had described in his testimony, due to the fact that he could not exactly see the car hitting a walking person since it was dark and he had a weak vision. ${ }^{7}$ Experiences show that the confidence of eye-witnesses is not solid enough at the time of the criminal offence, a seemingly innocent positive response or a simple 'all right' said by the interviewer can easily affirm it significantly. A strong influence on his decision makes him become more and more confident in what he was insecure before. ${ }^{8}$ To avoid unwillful, undesired or deliberate influencing of the witness's statement by the interrogator, it is necessary that the witness may coherently perform his statement verbally; nevertheless, the questions must be asked since they assist the witness to remember and fill up parts originally left out of his testimony, furthermore, it motivates the witness to disclose his cognisance he had deliberately wanted to conceal. ${ }^{9}$ Actually, to acquire an uninfluenced, honest and truthful testimony is one of the main tasks of the interrogation. If the credibility examination cannot be completed in the course of the interview, there are several other measures and equipment to assist the proceeding authorities

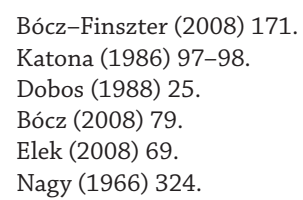


to confirm or confute the content of the testimony. Reconstruction is one of these measures. The defendant or the witness states something and the authority wants to confirm or confute the statement. Generally, the aim of the evidentiary proof is confuting the statement when the member of the proceeding authority does not believe the interviewed person and wants conviction on the verity of the testimony. If the results match with the testimony of the defendant or the witness, it shall be another argument roving that the interviewed person does not lie. On the contrary, if the results of the evidentiary procedure would confute the testimony, it confirms the authority's suspicion that the given event, phenomenon or action could not take place in the way the interrogated person described it. In this case, the evidentiary procedure might result in the interrogated person's confession, seeing no further point in lying or in denial.

Pursuing a credibility examination through reconstruction is not a new approach. Even during the era of Be. I, authorities have used it in the course of crime scene investigations to analyse the credibility of testimonies. Namely, in one of the cases, the injured party has stated in his testimony that "a stranger has hit him on the back of his neck when he was getting dressed, and he'd lost his consciousness, so he does not remember anything else." The police committee present at the site determined that István B. was hanged on the window handle by his own belt. The belt was laying on the table in the same state as it has been removed from his neck. A seriously wrinkled part of the belt has shown the place where the loop was tied. The head of the committee has immediately tied the loop and stood the injured person by the window, placing the belt around his neck. It turned out that the belt was still long enough, allowing the victim's legs to reach the floor comfortably. Reconstruction could confute the testimonies of the mother and other witnesses who previously stated that the victim's legs were hanging and twitching in the air. "So it could be determined that István B. has only made up this fantastic story so he could pretend to be a victim of spies before the German embassy, hoping to receive an appropriate award for his altruist services." ${ }^{10}$ Reconstruction is often used in traffic related criminal cases in order to detect whether the accident could have happened the way it was described in the defendant's and witness's testimonies, or the given injury of the vehicle could have occurred the way it was described in the testimonies. ${ }^{11}$ Reconstruction conducted for the purpose of credibility examination may be pursued both in the course of the investigation and during the court procedure. ${ }^{12}$ In the course of the court procedure, alongside with setting up the same conditions and repeating the actions before the court, the court may also check "certain details of the testimony, or the facts of the actual phenomenon or the possibilities and circumstances of the witness's cognisance". ${ }^{13}$ Back in the era of Be. II, the Supreme Court has declared that it is not necessarily possible to set the same circumstances or those most similar to the circumstances of the examined event during the court procedure. "In the present

\footnotetext{
Gyakorlati nyomozástan [Investigation Techniques] (1947) 140-141.

Budaházi (2017c)

Budaházi (2018) 209.

13 Nagy (1966) 363.
} 
case the vehicles involved in the action are not available, furthermore, the characteristics of the scene might also be important. Acquiring vehicles similar to those involved in the action or setting up the specific environment for the reconstruction cannot be completed in the court's authority" - pointed out the Supreme Court that approved to the county court's order on additional investigation. (Supreme Court, Bf.III.2.453/2001.) The Appeal Court of Szeged also agreed to the requirement according to which the reconstruction should be conducted under the same circumstances under which the examined event or phenomenon took place or could have taken place when disclosing the results of reconstruction from the line evidences. (Szeged Appeal Court, Bf.III.107/2014/4.) However, reproduction of the 'same circumstances' for the reconstruction cannot be entirely completed, not even during the investigation, but this should not cause any hindrances in the course of the execution of the procedural act, thus the relevance should always be the guideline. ${ }^{14}$ For example, if a vehicle hits a bicycle, it shall be relevant at the reconstruction focusing on visibility whether the bike used at the evidentiary procedure is a green male mountain bike or a female tracking bike.

\section{Palpability (perceptibility) experiments}

Such experiments focus on the palpability and the differences in the perceptibility, visibility, audibility and the sensibility to smells and tastes. Mostly, these are connected to a specific location, therefore the experiments must be completed at the site where the given phenomenon or event took place. My empirical survey based on questionnaires ${ }^{15}$ has confirmed (the questionnaire was completed by 185 detectives and 135 investigators) the personally experienced practice that reconstructions ordered on the grounds of checking visibility conditions are most typical. In such cases, reconstruction is held to clarify whether the witness could see the perpetrator's face, or if any object (for example, a billboard) was blocking the view at a traffic accident or at missing to follow a priority sign for which the suspect could not see the cyclist passing through a protected lane. Also, a visibility reconstruction was held in a case where the suspect hit a biker riding outside the residential area with no public lightning. The cyclist had no lights on and did not use a high visibility vest either. Therefore, reconstruction procedure was completed to confirm or confute whether the suspect could see the bicyclist or not. Or in another case, the focus of reconstruction was to determine whether the witness could see the suspect breaking up the vehicle's door with a wrenching bar from the third floor. The aim of the procedure was to clarify whether the witness could see the face of the perpetrator or the tool used to commit the crime in the evening hours. In another case of truculence conducted at dawn has raised the question whether the witness could visualise the action from the location he was standing according to his

\footnotetext{
Girhiny (2017)

Budaházi (2017a)
} 
statement. In the so-called 'Magda-case' authorities examined whether the witness could see the unknown man in every detail that allowed his later identification. ${ }^{16}$

\section{Determination of a time period with reconstruction}

Determination of the term necessary to complete certain operations, sequences of events or actions might be completed upon reconstruction. Basically, we must focus on evidentiary experiences, for example, the usual time necessary to take a certain distance. ${ }^{17}$ Determination of a certain period has always been subject to reconstruction objectives, it was a frequent example of crime scene investigations even at the beginning of the 1900s: "how far is one place from another if the rider is in full gallop." 18

The Appeal Court of Pécs has also faced a case whereas the second degree court and participating defendant have followed the track determined in the defendant's testimony. Upon the result of reconstruction, the second instance court stated that the track described by the defendant cannot be completed in 49 minutes - under the conditions set forth by the defendant -it would take 59-60 minutes at least. Therefore, the reconstruction completed during the second degree court procedure did not confirm the validity of the defendant's alibi, "it has fundamentally questioned the credibility of the defendant's testimony, his trustworthiness has failed". According to the appellate court's decision, "the reconstruction has proved beyond any doubt that driving the vehicle the defendant could not have completed the track described in his testimony within the time frame available in accordance with the objective evidences". ${ }^{19}$

\section{Reconstruction focusing on the clarification of the execution possibilities of an operation or action}

The characteristics of reconstruction is that the authority gains perceptive cognisance of the fact to be proved - the site, the sub alternation of the events or the artificially generated action. ${ }^{20}$ For example, the aim of the procedure was to clarify the execution possibilities of an action when they examine what kind of injuries the given object may cause. ${ }^{21}$ They examine whether the victim's injury could occur the way it has been told by the injured party and the witnesses. In one of the cases, the injured party stated that after the suspect committed grievous bodily injury against him, he also pulled a semi-trailer truck on him when he was escaping and scrabbling up to his feet, causing further injuries to him. During the reconstruction, they have analysed whether the narrow space allowed the semi-trailer truck to turn and reach the victim, furthermore,

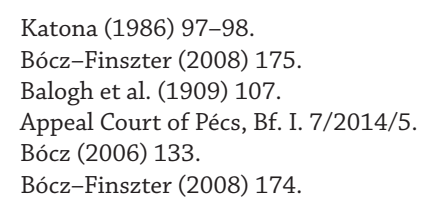


if the suspect could detect the location of the victim sitting in the driver's seat of the vehicle. Another case, where the possible execution was examined with reconstruction was checking whether the given quantity of boxes of cigarettes could fit in a certain bed linen in case they were randomly dropped in it instead of systematic packing.

\section{Recognition of peculiar characteristics and abilities}

Reconstruction may also be sufficient to detect certain personal, individual characteristics of the participants of the examined events (their physical state, dexterity, skills), competences (for example, adaptive competences, senses of visuality and audibility, personal stimulation threshold, etc.). ${ }^{22}$

In a larceny case, the investigating authority has examined whether the suspect could pass through the window he stated to cross to steal the assets from the house, as he previously stated in his testimony. A similar example was the examination of a sack used for conducting the offence, measuring the quantity of corn and determining whether the suspect was able to take it from the crime scene. Another reconstruction procedure has also focused on individual characteristics, determining the number of perpetrators, whereas the victim was shot in the head in a phone booth, in other words, checking whether any other person could fit into the telephone booth besides the perpetrator and the victim.

The introduced methods represent that several questions can be clarified through reconstruction that seem essential for successful completion of a certain criminal case.

\section{Factors Impeding Reconstruction}

One of the main reasons of the rare practice of reconstruction is that the majority of the cases does not even require this evidentiary procedure..$^{23}$ In other words, there is no data or information that should be confirmed or confuted by the reconstruction of the criminal act; however, in other cases the issue would require this criminal procedure, but the available evidence is sufficient to detect and prove the state of facts, thus ordering reconstruction is unnecessary.

For reconstruction cases it is quite common, that the testimonies of the suspect and the witness are contradictional, or one of the testimonies contradict the experiences of everyday life (absurd statements). For example, during his interrogation, the suspect states that he had lifted the cash box over the bench by himself. It is also typical, that reconstruction is only conducted in cases of 'high priority', when the investigating authorities cannot spare the extra working efforts and costs the reconstruction requires, not to mention the time factor, that is also crucial for this procedural act (both the preparation and the execution are time-consuming, the latter takes significant time

\footnotetext{
22 Bócz-Finszter (2008) 175.

23 Budaházi (2014) 187.
} 
due to detailed mandatory documentation). Depending on the nature of the reconstruction, several conditions must be jointly met, so that the evidentiary procedure can be held at all. It is enough to think of weather issues, for example, winter surroundings should be reconstructed during the summer. Likely, if the local or disputed circumstances are significant, a reasonable reconstruction should only be held at the actual site and under the same outside (weather, lighting conditions, etc.) circumstances as they were at the time of the actual event, otherwise only the most determining aspects of the event should be simulated. For example, if the task is to determine whether the suspect is able to open a certain type of lock with a piece of bended wire - as he previously stated -the given calendar season, time of the day, light and weather conditions have no significance whatsoever. On the other hand, if the fact whether a train passing in the cover of a treeline can be seen at the given point of a crossing public road (visibility, audibility), obviously, the time of the year and the day, moreover, several other meteorological factors can be crucial. ${ }^{24}$

Besides the heavy workload of the proceeding authorities, further obstacle to order reconstruction is that its execution requires a relatively large number of staff and special equipment. In some cases, further assistance is needed to set the site, etc., furthermore, a crime scene technician who handles the camera or shots picture at the criminal procedure, a car similar to the one in which the victim was sitting might also be required, or a bicycle to replace the injured party's wrecked bike. If the victim was injured during the accident, a stuntman with similar physical characteristics is needed, wearing similar clothing as the victim wore at the time of the accident. The public road must be closed for the duration of the reconstruction; moreover, it must be completed under the same weather and light conditions that characterised the time of the accident. Besides, proper subpoena (addressed to the defendant, witness, expert - depending on the time of the evidentiary action) and notices (for example, the legal representative of the witness, defence attorney of the defendant) must be sent, including the arrangement of the date and the notification on the appointment of the experts. Preparation and organisation of the procedural act can be even more complicated if the prosecutor or high ranking police officers wish to participate at the procedural event. Of course, there are several other tasks to complete before the reconstruction, so I have only emphasised the most frequent and important ones, indicating the reasons why the organisation of the reconstruction is complicated and circumstantial, so, actually, they do not order it very often, unless it is a must.

Moreover, other problems may also occur, for example, there is no appropriate technical device (for example, a camera) to record the procedural act, or if there is one, actually it is the officer of the investigation authority who objects to conduct the reconstruction, in fear, that he would make a mistake or fail to act professionally due to the stage fright he would feel during the recording. Further excuse against reconstruction is that usually this procedural act is held in an outdoor location, so usually official

24 Bócz-Finszter (2008) 174. 
vehicles are necessary to complete the process, and these are not always available in the required quantity. Although stand-ins are allowed to replace the real participants, there are certain cases where successful completion of the reconstruction requires the personal presence of the witness or the defendant. Practice shows - confirmed by the filled questionnaires - that the participation of stuntmen is not very common and the investigating authorities seek to have all parties playing their own roles.

There is a possibility that the following reasons motivate the suspect not to take part in the reconstruction:

- fear of identification;

- he does not want (a new) incriminating evidence;

- he shall rather wait for the results of the reconstruction and shall modify his testimony accordingly, if needed;

- he does not want to flounder in his statement;

- he feels inconvenient in the presence of others (especially, if the reconstruction takes place in a public area, in the presence of browsers);

- advice of the defence attorney;

- he wants to obstruct the investigation;

- he does not want to recall and relive the offence he had committed.

Mostly, the nature of the case drives the defendants' (low) affinity to participate at the reconstruction, while witnesses are more likely to participate, principally, due to their mandatory obligation of active participation at reconstructions.

However, there are reasons that motivate witnesses to stay absent from the reconstruction:

- fear from identification;

- fear from incriminating relatives;

- "he does not feel like participating";

- psychological reasons;

- he is staying abroad; ${ }^{25}$

- he does not want to meet the suspect, maybe fears the suspect;

- he is concerned, that the eventually negative results of the reconstruction would question his trustworthiness;

- he does not want to relive the event again;

- he is not convinced that what he told is true, and he is afraid from the consequences of his mistake, or otherwise would feel ashamed if the falseness of his statement would be revealed.

For example, it may occur at the last reason that the witness is wrong, ${ }^{26}$ regardless of the fact that he is trying to answer the questions addressed to him according to his best

\footnotetext{
25 Budaházi (2015) 131.

26 Dobos (1988) 25.
} 
knowledge, but his statements prove to be false. ${ }^{27}$ His mistake might originate in the falseness of his observations or mistaken memory, ${ }^{28}$ and after being interrogated he starts to realise his mistakes, he becomes more and more insecure, but still, he does not want to reveal his delusions.

Finally, we must mention the factor according to which many detectives are without the necessary and appropriate professional expertise, so their general fear from anything new becomes an obstacle of initiating reconstruction. This is further topped by the impression of more experienced officers, according to which prosecutors or judges clearly underestimate the importance of reconstruction, evaluating its results as one of the possible occurrences of the event, phenomenon or action.

\section{Malfunctions of Execution that May Influence the Results of Reconstruction}

The 'danger scale' of Csaba Fenyvesi deems it uncertain if the reconstruction results in a wrongful exemption, resulting in the perpetrator's escaping criminal liability. ${ }^{29} \mathrm{On}$ the other hand, errors may cause false affirmation of reasonable suspicion that may lead to false adjudication whereas an innocent person faces accusation.

A few danger factors that could affect the success of reconstruction:

- inappropriate preparation of the execution;

- no preparation for unexpected events (for example, a 'B' plan for rainy weather);

- inappropriate munities of the preliminary crime scene investigation;

- imprecise official record taken at the reconstruction, so the court cannot approve the results;

- use of a different object from the one the perpetrator used to commit the offence at the reconstruction, the tool used is not even similar to the original;

- the stuntman does not look like the person replaced (different outfit, physical parameters, height, etc.);

- the investigating authority does not even try to create the same or at least similar circumstance as they were at the occurrence of the given event, action or phenomenon;

- no video recording has been taken;

- inappropriate audio- or visual recordings of the action;

- reconstruction of the event in rain, despite the fact that the examined even has taken place in clear weather;

- the investigating authority does not detect the extenuative circumstance (the suspected perpetrator should be disclosed from the procedure, but the authority fails to do so);

\footnotetext{
Elek (2008) 23.

Gyakorlati nyomozástan [Investigation Techniques] (1947) 37.

Fenyvesi (2017) 173.
} 
- inappropriate communication of the head officer of the reconstruction, failing to give unambiguous instructions to the participating offices, misplaces the participants of the reconstruction;

- the detective controls and influences the subject more than it is necessary;

- the authority loses control over the execution of the reconstruction;

- the authorities fail to interview the suspect or the witness, or in case they do, they miss to ask the questions necessary to clarify the circumstances expressly stipulated in Section 63 of the Nyer.;

- premature reconstruction;

- injured guarantees, failure of mandatory notifications so the defence lawyer or the legal representative of the witness cannot attend to the evidentiary procedure;

- lack of professional experience, due to the rare practice of reconstruction and to the high number of young police officers.

\section{Closing Remarks}

In this study, I aimed to outline how reconstruction may contribute to the successful closure of the criminal procedures in many aspects, nevertheless, I have pointed out that the preparation and conclusion of the reconstruction is quite time consuming and requires considerable extra work compared to other procedural acts. These factors lead to its rare practice, but on the other hand, in most cases there is simply no need to initiate the reconstruction procedure. However, the rare practice does represent an error factor, so consequently, if the proceeding authority conducts a reconstruction, it is advisable to prevent and eliminate the potential mistakes enlisted in this study. I do believe that reconstruction does have solid grounds and a significant role after the coming into force of the Be. IV as well, regardless of its numerous boundaries. As of the regulatory provision, we may state that the mandatory rules are efficient, there is no need to implement new statutory rules or to modify the present regulations either. It is not by accident that the statutory provisions on reconstruction have stayed in force for decades.

\section{REFERENCES}

Appeal Court of Pécs, Bf. I. 7/2014/5.

Balogh Jenő - Edvi Illés Károly - Vargha Ferenc (1909): A Bünvádi perrendtartás magyarázata. Második kötet, Budapest, Grill Károly Könyvkiadó Vállalata.

Bócz Endre (2006): Büntetöeljárási jogunk kalandjai - sikerek, zátonyokés vargabetük. Budapest, Magyar Hivatalos Közlönykiadó.

Bócz Endre - Finszter Géza (2008): Kriminalisztika joghallgatóknak. Budapest, Magyar Közlöny Lapés Könyvkiadó. 
Budaházi Árpád (2014): Bizonyítási kísérlet a büntetőeljárás szolgálatában. In Gaál Gyula - Hautzinger Zoltán eds.: Tanulmányok a „Biztonsági kockázatok-rendészeti válaszok” címü tudományos konferenciáról. Pécs, Pécsi Határőr Tudományos Közlemények, XV.

Budaházi Árpád (2015): Bizonyítási kísérlet a felderítésben és a bizonyításban. In Gaál Gyula Hautzinger Zoltán eds.: Modernkori veszélyek rendészeti aspektusai. Pécs, Pécsi Határőr Tudományos Közlemények, XVI.

Budaházi Árpád (2017a): A bizonyítási kísérlet egy empirikus kutatás tükrében. Magyar Rendészet, Vol. 17, No. 5. 67-82.

Budaházi Árpád (2017b): A bizonyítási kísérlet és történeti előzményei. Magyar Rendészet, Vol. 17, No. 4. 33-46.

Budaházi, Árpád (2017c): Personal and Material Evidences in Criminal Procedure, with Particular Attention to Road Traffic Crashes. Studia Universitatis Babes-Bolyai, Iurisprudentia, No. 2. DOI: https://doi.org/10.24193/SUBBiur.62(2017).2.5

Budaházi Árpád (2018): A bizonyítási kísérlet büntető eljárásjogi és kriminalisztikai aspektusai. Magyar Jog, Vol. 65, No. 4. 202-209.

Dobos János (1988): Kis nyomozástan. Budapest, BM Könyvkiadó.

Fenyvesi Csaba (2017): A bizonyítási kísérlet és a hit. Iustum Aequum Salutare, Vol. 13, No. 1. 99-106.

Elek Balázs (2008): A vallomás befolyásolása a büntetőeljárásban. Debrecen, Tóth Könyvkereskedés és Kiadó Kft.

Girhiny Kornél (2017): The Relevancy of Questioning on the Scene in Case of Exhibits. Studia Universitatis Babes-Bolyai, Iurisprudentia, No. 2.95-101. DOI: https://doi.org/10.24193/SUBBiur.62(2017).2.10

Gyakorlati nyomozástan [Investigation Techniques](1947). Budapest, Magyar Államrendőrség Országos Szaktanulmányi Felügyelője.

Katona Géza (1986): Még egyszer Magda János bűnügyéről. Belügyi Szemle, Vol. 24, No. 8. 96-104.

Nagy Lajos (1966): Tanúbizonyítás a büntetőperben. Budapest, Közgazdasági és Jogi Könyvkiadó.

Vári Vince (2014): Hatékonyság a nyomozásban. In Schaub Anita - Szabó István eds.: III. Interdiszciplináris Doktorandusz Konferencia. Pécs, Pécsi Tudományegyetem Doktorandusz Önkormányzat. 